\title{
Az egészségjelentések jó gyakorlata - irányelvek és ajánlások
}

\author{
Good Practice in Health Reporting - guidelines and recommendations
}

\author{
Szerző: $\quad$ Vitrai József $\square$ \\ Nemzeti Népegészségügyi Központ
}

Beküldve: 2018.11.05.

doi: $\quad$ 10.24365/ef.v59i6.380

Kulcsszavak: egészségjelentés; irányelv; ajánlás

Keywords: health reporting; guideline; recommendation

Az egészségjelentések készítését támogató irányelveket és ajánlásokat egy, az egészséginformáció előállításában helyi, tartományi és szövetségi szinten részt vevő, különböző szakterületek képviselőinek munkacsoportja készítette. ${ }^{1} \mathrm{~A}$ dokumentumot a Német Társadalomorvoslási és Megelőzési Társaság (German Society for Social Medicine and Prevention), a Német Epidemiológiai Társaság (German Society for Epidemiology) valamint a Német Népegészségügyi Tanszékek Orvosainak Szövetségi Társasága (Federal Association of Physicians of German Public Health Departments) kibővitett vezetősége hagyta jóvá. A dokumentum 11 irányelvet és azokhoz kapcsolódó 23 ajánlást fogalmaz meg az egészségjelentés készítésének különböző feladataihoz, így az etikai kérdésekhez, a jelentés elméleti kereteihez, a témaválasztáshoz, a minőségbiztosításhoz, az adatok előkészítéséhez, elemzéséhez, értelmezéséhez, az adatvédelemhez és kommunikációjához. A dokumentum közlését követő visszajelzések figyelembevételével a szerzők egy újabb változatot fognak közreadni.

Az egészségjelentés - a dokumentum meghatározása szerint - a lakosság egészségének értelmezett leírása, amely elemzi az egészséggel kapcsolatos problémákat, bemutatja az egészségügyi ellátás, az egészségfejlesztés és a betegségmegelőzés azon területeit, ahol beavatkozásra van szükség. Célja, hogy megfelelő információkat biztosítson a lakosság számára a közösségi részvétel szervezéséhez és az egészségpolitikusoknak a szakpolitikai döntések megalapozásához. Az egészségjelentés ezáltal az egészségügyi szakpolitika egyeztetési folyamatának része, mert

- bemutatja a lakosság egészségét befolyásoló kockázatok és lehetőségek egyenlőtlen társadalmi és földrajzi eloszlását, rámutat a szükséges szövetségi, tartományi és helyi szintű beavatkozásokra a betegségmegelőzés területén;

- alapot nyújt az egészségfejlesztés és a betegségmegelőzés tervezéséhez és a népegészségügyi intézkedések értékeléséhez;

- folyamatosan gyújt információt a lakosság egészségéről, és korán jelzi a bekövetkező változásokat, ezzel lehetőséget nyújtva a gyors szakpolitikai beavatkozásokhoz;

- nemcsak a döntéshozóknak és a szakértőknek nyújt információt, hanem a lakosságot is tájékoztatja;

- támogatja a közösségi vélemények formálódását lehetőséget kínálva a szakpolitikai célok kitǔzésében való részvételhez.

$\mathrm{Az}$ egészségjelentések célkitúzésének tárgyalása után a dokumentum az egészségjelentés-készités alapvető elméleti és gyakorlati követelményeit veszi sorra. Így a jelentések alapjául szolgáló adatforrá- 
sokat, adatköröket, az alkalmazandó különböző diszciplínákat, szakterületeket. Számba veszi továbbá az egészségjelentés elkészítéséhez az erőforrás- és időszükségletet is.

Az irányelvek és ajánlások mellett a dokumentumban egy 7 oldalas ellenőrző lista található az egészségjelentést készítők számára a tudományos megalapozottság, a jelentéskészítés, a stílus, a formázás és terjesztés, a tartalom, az adatok minősége, az elemzés valamint az eredmények értelmezése, következtetések és ajánlások témájában.

\section{HIVATKOZÁSOK}

${ }^{1}$ Starke D, Tempel G, Butler J, Starker A, Zühlke C, Borrmann B. Good Practice in Health Reporting - guidelines and recommendations. Journal of Health Monitoring. 2017 2(S1). DOI 10.17886/RKI-GBE-2017-013 